DOI: 10.20472/IAC.2019.050.010

KRYSTIAN DUCZEK

University of Szczecin, Poland

\title{
CHALLENGES FOR THE EUROPEAN GOVERNMENTS REGARDING THE CHINA'S ONE BELT ONE ROAD INITIATIVES IN EUROPE
}

\begin{abstract}
:
The author of the poster will present issues that are raised in front of the European governments regarding the completion of cooperation in the construction of the China's One Belt One Road Initiatives that has an impact on increasing the import and export between Europe and China. The author will also present the possibilities to reduce the trade deficit of imports and exports between Europe and China. Will discuss the issue related to the construction of a transshipment port in Lodz Poland and the impact of this project on the stronger position of Poland in the European Union and the measurable benefits of creating a "transshipment center and warehouse for Europe". The author will also undertake analysis of the recent political and economic decisions which are having a strategic significance on the prospective development of the China's One Belt One Road Initiatives.
\end{abstract}

\section{Keywords:}

International business, The New Silk Road, International policy, China, Transportation 